\title{
Immunogenicity of a recombinant coronavirus spike glycoprotein expressed in transgenic plants
}

\section{Summary}

Recently, it has been demonstrated that plants offer the possibility of producing low cost subunit vaccines that can be either parenterally or orally administered. Here we review data we obtained on the immunological response elicited by two recombinant versions of the glycoprotein $\mathrm{S}$ from the swine transmissible gastroenteritis coronavirus (TGEV) expressed in transgenic plants. Arabidopsis or potato plants were genetically transformed with cDNAs constructs encoding the $\mathrm{N}$-terminal domain (aa residues 1-750) or the full-length glycoprotein $S$ of TGEV, responsible for the neutralizing antibody induction against the virus, under the control of the cauliflower mosaic virus $35 \mathrm{~S}$ (CaMV 35S) promoter.Genomic DNA and mRNA analysis of leave extracts from transformed plants demonstrated the incorporation of the foreign CDNA into the plant genomes as well as their transcription. Expression of recombinant polypeptides was observed in most transgenic plants by ELISA using specific antibodies. Mice immunized either parenterally with leave extracts from transgenic arabidopsis plants or, more interestingly, fed with potato tubers, developed antibodies that specifically reacted with TGEV in ELISA, immunoprecipitated the glycoprotein $S$ and in some cases neutralized the virus infectivity. From the above results, we conclude that transgenic plants expressing glycoprotein $\mathrm{S}$ polypeptides may be potentially used as a source of recombinant antigen for vaccine production.

\section{Key words}

Genetically modified plant Vaccine . Coronavirus · TGEV

Swine transmissible gastroenteritis virus (TGEV) is the causative agent of acute diarrhea of newborn piglets that provokes high rate mortalities in affected farms. Protective immunity against this disease has to be developed in pregnant sows in order to confer passive protection to the piglets trough colostrum and milk. Neutralizing antibodies against the virus are directed mainly to glycoprotein $S[1,2]$, and relevant epitopes in neutralization have been mapped into the $\mathrm{N}$-terminal domain of this protein [3]. Four major antigenic sites have been described in glycoprotein $S$, of which site $A$ is the immunodominant $[4,5,6]$. Only vectors expressing the glycoprotein $\mathrm{S}$ with tropism that favored antigenic presentation in the mucosal surfaces have conferred protection against TGEV in suckling piglets [7].

Durch Expression immunogener Proteine von Krankheitserregern in Pflanzen könnten essbare Impfstoffe in grosser Menge und zu geringen Kosten hergestellt werden.
The concept of vaccine production in transgenic plants was first introduced by Mason and co-workers in 1992 [8]. Proteins involved in protective immune response can be produced at a low cost and easily purified from plant extracts for parenteral inoculation. In addition, oral immunization by edible vaccines produced in transgenic plants could stimulate immune responses at the portal of entrance for many pathogens, facilitating the design of large-scale immunization programs. The presence of specific antigens in plants, even at low levels, can raise immune reactions by the oral route comparable to conventional vaccines $[9,10,11]$.

Today, hepatitis B surface antigen [12], E. coli heat-labile enterotoxin (LTB) antigen [9], Norwalk virus capsid protein [8], VP1 antigen from foot and mouth disease virus [11,13], Cholera toxin B subunit [14], glycoprotein S from swine transmissible gastroenteritis virus [15], and VP6o from rabbit hemorrhagic disease virus [16] are vaccine antigens expressed in transgenic plants and tested for the immune response elicited in immunized animals. Here, we review the data obtained about the feasibility of expressing the glycoprotein S

Dr. José M. Escribano Departamento de Mejora Genética y Biotecnologia, INIA, Ctra de la Coruna Km 7. 28040 Madrid, Spain 


\section{J.M.Escribano · M.V. Borca}

\section{Immunisierende Wirkung eines rekombinanten Coronavirus-Proteins aus transgenen Pflanzen}

\section{Zusammenfassung}

Kürzlich wurde gezeigt, daß es mit Hilfe von Pflanzen möglich ist, kostengünstig Untereinheiten von Vakzinen zu produzieren, die entweder parenteral oder oral angewendet werden können. Hier berichten wir über die immunologische Reaktion, die durch zwei in Pflanzen exprimierte, rekombinante Versionen des Glycoproteins S des Coronavirus der transmissiblen Gastroenteritis des Schweines (TGEV) hervorgerufen worden ist. Arabidopsis- oder Kartoffel-Pflanzen wurde gentechnisch verändert mit cDNA-Konstrukten, die für die N-terminale Domäne (Aminosäuren 1 bis 750) oder für die gesamte Länge des Glycoprotein S aus TGEV kodieren und unter der Kontrolle des 35 S Promoters des Cauliflower Mosaic Virus (CaMV) stehen; das Glycoprotein S bewirkt die AntikörperInduktion gegen TGEV. Die Analyse von genomischer DNA und von mRNA aus Blattextrakten der transformierten Pflanzen beweisen sowohl die Integration der FremdDNA in das Pflanzen-Genom als auch ihre Transkription. Die Expression der rekombinanten Polypeptide wurde in den meisten transgenen Pflanzen im ELISA-Test durch spezifische Antikörper nachgewiesen. Mäuse, die parenteral mit Blattextrakten von transgenen Arabidopsis-Pflanzen oder, weit interessanter, oral mittels transgener Kartoffelknollen immunisiert worden waren, entwickelten Antikörper, die im ELISA-Test spezifisch mit TGEV reagierten, das durch den Virus induzierte Protein immunprezipitierten und in einigen Fällen die Virusinfektion aufhoben. Aufgrund dieser Ergebnisse sind wir der Meinung, daß transgene Pflanzen, welche Glycoprotein-S-Polypeptide exprimieren, möglicherweise benutzt werden können, um rekombinantes Antigen zur Herstellung entsprechender Vakzine zu produzieren.

\section{Schlüsselwörter}

Gentechnisch veränderte Pflanze · Vakzine · Coronavirus - TGEV from TGEV in two different transgenic plants, as well as the antigenicity and immunogenicity of the plant-derived protein administered either parenterally or orally to mice. The protein $S$ is an excellent model for developing oral vaccines against enteric pathogens of mammals because of its immunogenicity and resistance to degradation in the gut.

\section{Results}

\section{Arabidopsis and potato plant transformation}

The binary pRoK I and pRoK II recombinant plasmids (Fig. 1), carrying a cDNA coding for the $\mathrm{N}$-terminal region or the full-length glycoprotein $\mathrm{S}$ respectively, were obtained by subcloning the corresponding sequences from previously obtained constructs into pRoK 2 plasmid [17]. Recombinant pRoK derived plasmids allow selection of transformants on media containing kanamycin and stable integration into nuclear chromosomal DNA from the plant. PRoK 2 uses the CaMV 35 S promoter to drive nominally constitutive transcription of the cloned genes.

Plant transformation with pRoK I and II was carried out as described [16, 18] by A. tumefaciens-mediated transformation. Potato plants were transformed only with pRoK I plasmid. The transgenic plants resistent to the selective medium appeared similar in morphology to non -transgenic plants. More than 20 different lines of arabidopsis transformants containing each construct were self-pollinated to obtain F2 lines. Fifteen different transformed potato clones were also obtained with pRoK I. All lines from arabidopsis and potato were positive when screened for the presence of the recombinant genes by PCR analysis (Fig. 1, A1 and B1). Most plants harboring recombinant genes showed specific transcription of foreign genes by RT-PCR analysis (Fig. 1, A2).

\section{Recombinant glycoprotein S expression in transgenic plants}

The presence of the recombinant polypeptides in the plants harboring and expressing the foreign genes was investigated by ELISA and Western blot using an anti-TGEV polyclonal serum. Results demonstrated that leave or potato ex- tracts from all analyzed plants resulted positive in ELISA (Fig. 1, A3 and B2). However, no specific reaction in Western blot was detected in any of the plant extracts analyzed (data not shown), probably due to the low levels of recombinant protein expression and to the conformational nature of most of the immunodominant epitopes present in this protein.

From a titration ELISA using different virus dilutions and a monospecific anti-glycoprotein $S$ antibody, we have found that about $30-60 \mu \mathrm{g}$ of soluble leave or tuber protein contain a glycoprotein $S$ antigenic mass equivalent to that contained in $0.02 \mu \mathrm{g}$ of purified TGEV. The percentage of the total soluble protein corresponding to recombinant glycoprotein $\mathrm{S}$ polypeptides accumulated in the tissues of plant transformants could represent between 0.06 to $0.03 \%$ of the total soluble protein.

\section{Immunogenicity of the plant-derived glycoprotein S polypeptides}

Leave extracts from transgenic arabidopsis plants expressing the $\mathrm{N}$-terminal or full-length glycoprotein S, were used to immunize mice. A control mouse was immunized with a leave extract from a plant transformed with pRok 2 plasmid. After three immunization doses $(40 \mu \mathrm{g}$ of total protein per animal per injection), the specificity of mice sera was tested by an ELISA using purified TGEV as antigen. Figure 2 (A1) shows that all sera reacted with the virus showing, as expected, different titers. Mice developed specific antibodies against glycoprotein $S$ after 2 immunization doses (Fig. 2, A2).

\section{Durch Injektion von Pflanzenextrakt oder Verfütterung transgener Pflan- zen konnte in Mäusen eine spezifische Antikörperbildung gegen das TGEV- Glykoprotein Sinduziert werden.}

Sera from all immunized mice were tested in a TGEV neutralization assay. Both glycoprotein $S$ polypeptides produced in transgenic plants elicited virus neutralizing antibodies (neutralization indexes between 2.2 and 3.5; Fig. 2, A3). Serum from a nonimmunized mouse or from the mouse immunized with the plant transformed with pRoK 2 plasmid did not show virus neutralization activity (Fig. 2, A3). Transgenic potato tuber ex- 


\section{Leitthema: Perspektiven zur Entwicklung der „,Grünen Gentechnik"}

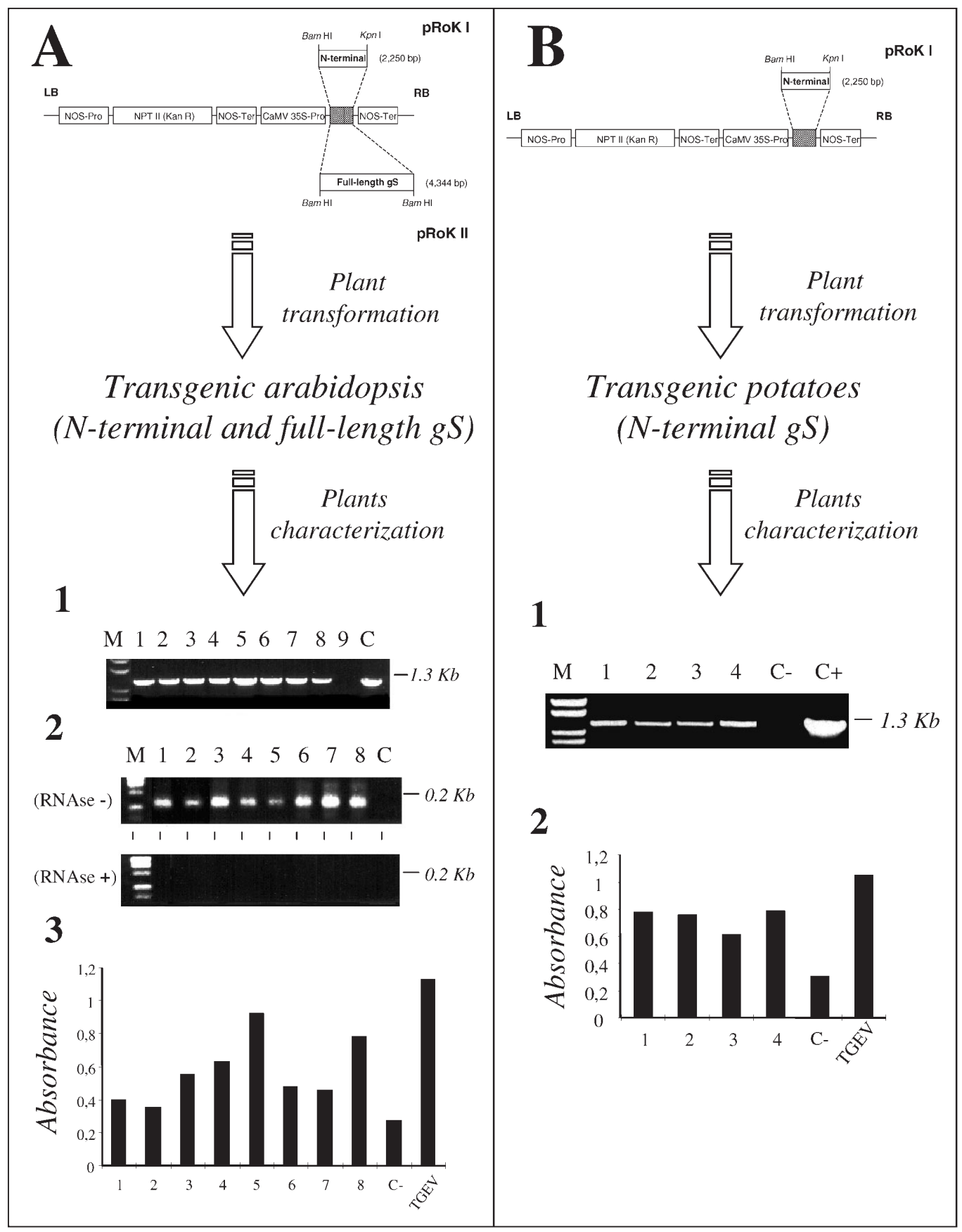

Fig. $1 \Delta$ Characterization of transgenic arabidopsis (A) and potato plants (B). In this figure the schematic structure of the binary plasmids pRoK I and II used for Agrobacterium-mediated plant transformation is represented.

The DNA sequence encoding for the full-length or N-terminal domain of glycoprotein S from TGEV was cloned downstream of the CaMV 355 promoter in recombinant pRoK plasmids, followed by the nopaline synthase (NOS) terminator. These plasmids contain the left (LB) and right (RB) borders of transferred DNA that demarcates the sequences that are incorporated into the plant genome. Panel A. (1) Presence of the recombinant genes in representative transgenic arabidopsis plants detected by PCR. Plants 1 to 4 transformed with pRoK I,5 to 8 with pRoK II, 9 with pRoK 2.C represents the control amplification of the same DNA fragment from pRoK II. (2) Foreign gene transcription in representative transformed plants analyzed by RT-PCR, in presence or absence of RNAse. (3) Detection of glycoprotein S polypeptides in protein extracts from transgenic plants by ELISA. Absorbance readings were obtained from arabidopsis leaves extracts transformed with pRoK I ( 1 to 4 ) and pRoK II (5 to 8). Positive control is purified virus (TGEV) and negative control is a plant transformed with pRoK 2 plasmid (C-). Panel B. (1) Presence of the recombinant gene (encoding the globular part of the glycoprotein $\mathrm{S}$ ) in representative transgenic potatoes ( 1 to 4 ) detected by PCR. Plants transformed with pRoK 2 (C-) and amplification of the same DNA fragment from pRoK I (C+) is also shown. (2) Detection of N-terminal domain of glycoprotein $\mathrm{S}$ in protein extracts from transgenic plants by ELISA. Absorbance readings were obtained from potato tuber extracts transformed with pRoK I. Positive control is purified virus (TGEV) and negative control is a plant transformed with pRoK 2 plasmid (C-). 


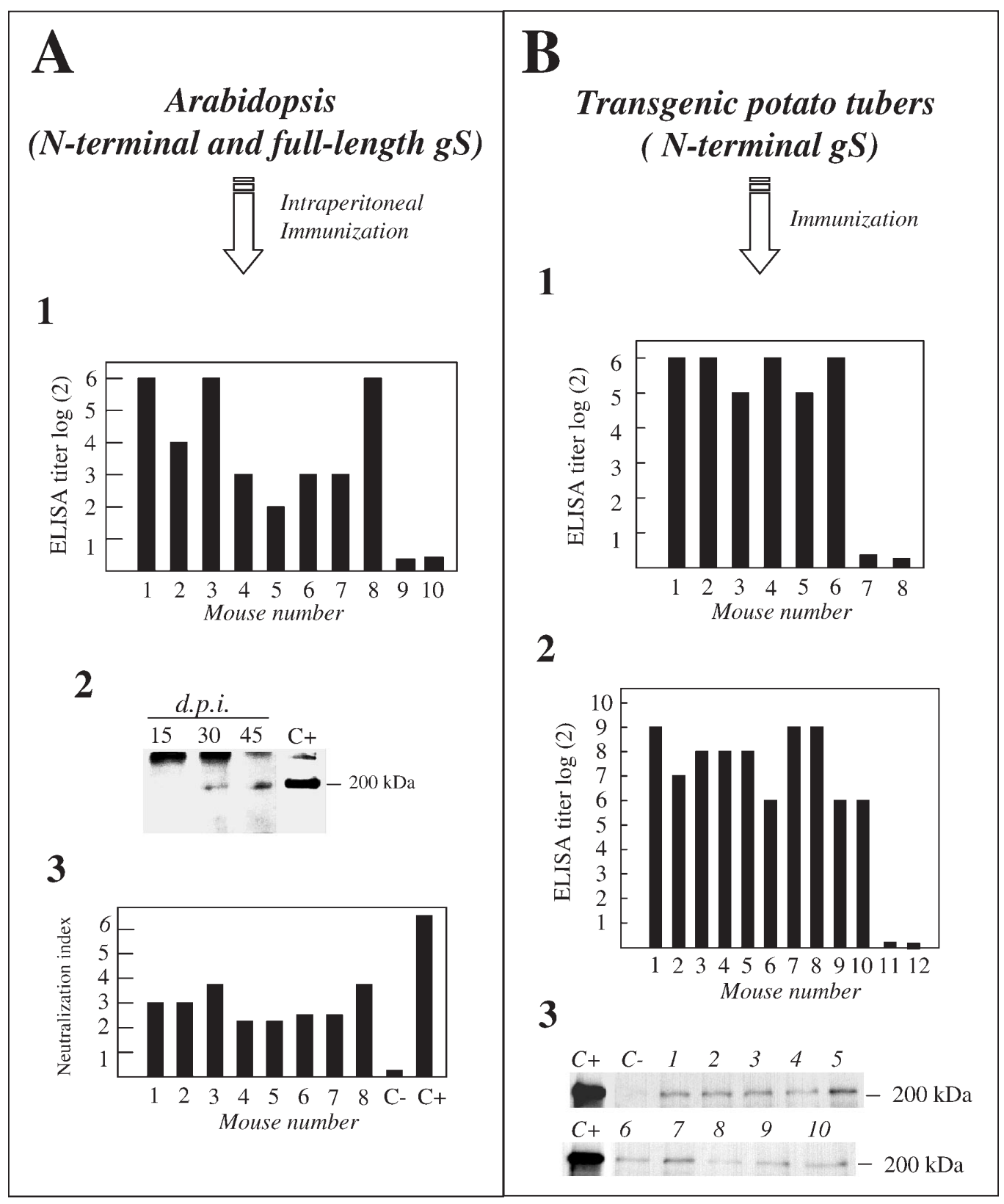

Fig. $2 \Delta$ Antibody responses to the plant-derived glycoprotein S polypeptides in immunized mice. Panel A. (1) ELISA titers of sera from mice inoculated with arabidopsis plant extracts expressing the $\mathrm{N}$-terminal (mice 1 to 4 ) or the full-length glycoprotein S (mice 5 to 8), using purified TGEV as antigen.

Mice 9 and 10 represent ELISA titers of two mice immunized with a pRoK 2 transformed plant extract. (2) Immunoprecipitation of glycoprotein $S$ induced by TGEV by sera from an immunized mouse after one (15), two (30) or three (45) immunization doses with transgenic plant extracts. A pool of monoclonal antibodies against glycoprotein $S$ was used as control $(C+)$. (3) Neutralization indexes of sera from immunized mice with plant extracts expressing the $\mathrm{N}$-terminal (mice 1 to 4 ) or full-length glycoprotein $\mathrm{S}$ (mice 4 to 8). The neutralization index is defined as the ratio between the log of virus titer in the presence of a control mouse serum and sera from mice immunized with transgenic plants expressing the antigens ( 1 to 8), or transformed with pRoK 2 (C-). A rabbit anti-TGEV serum showing high neutralization titer was also used as positive control $(C+)$. ELISA and neutralization index values are the mean of three independent experiments. Panel $\mathrm{B}$, (1) ELISA titers of sera from mice inoculated intraperitoneally with potato tuber extracts expressing the Nterminal domain of glycoprotein S (mice 1 to 6), using purified TGEV as antigen. Mice 7 and 8 represent ELISA titers of two mice immunized with a pRoK 2 transformed plant extract. (2) ELISA titers of sera from orally immunized mice with transgenic potato tubers expressing the $\mathrm{N}$-terminal domain of glycoprotein S (mice 1 to 10). Mice 11 and 12 represent ELISA titers of two mice immunized orally with a pRoK 2 transformed potato. (3) Immunoprecipitation of glycoprotein $S$ expressed by a recombinant vaccinia virus by antibodies present in sera from orally immunized mice with potato tubers expressing the $\mathrm{N}$-terminal domain of the glycoprotein. A pool of specific monoclonal antibodies was used as a control positive serum $(C+)$ and a serum from a mouse immunized with potato tubers transformed with pRoK 2 was used as a negative control (C-) 
tracts also induced specific antibodies in immunized mice using the same immunization protocol (Fig. 2, B1).

Finally, to analyze the oral immunogenicity of glycoprotein $S$ expressed in potato plants, a group of mice were fed with transgenic potato tubers expressing the N-terminal domain of glycoprotein $\mathrm{S}$. The animals were fed three times per week with two gram of transgenic potatoes during a two months period. Sera from these animals were analyzed by ELISA showing an specific antibody response against the plant-derived glycoprotein S, indicating the oral immunogenicity of this protein when expressed in plants (Fig. 2, B2). As expected, no antibody response was detected in mice fed with potato tubers not expressing the glycoprotein S. The specificity of sera reactivity in ELISA with the virus-induced protein was confirmed by immunoprecipitation of glycoprotein $S$ expressed by a recombinant vaccinia virus (Fig. 2, B3).

\section{Discussion}

In this report we show that full-length or the globular part (N-terminal domain) of TGEV spike protein (glycoprotein S) expressed in transgenic plants retained the antigenic properties and elicited neutralizing antibodies when used to immunize animals. Expression in eukaryotic hosts is required for antigenic determinants that are dependent on glycosilation. Of the three major antigenic sites defined on glycoprotein S involved in the induction of TGEV-neutralizing antibodies, sites A and B are complex, conformational, and glycosilation dependent. Site D can be represented by synthetic peptides, although glycosylation has a minor effect on its conformation [19]. Several genetically engineered vaccines using prokaryotic vectors have failed against TGEV. Glycoprotein S expressed at high levels in Escherichia coli and used to inoculate animals did not induce neutralizing antibodies or confer protection in vivo [20].

Plant cells present differences in protein glycosilation with respect to animal cells that could determine the loss of antigenic determinants in antigens expressed in transgenic plants. Glycosylation in plants may differ in the extent of glycosylation, processing, or both of
$\mathrm{N}$-linked oligosaccharide side chains [21]. Furthermore, the complex glycans of plants are often smaller than those of animals in part due to the absence of sialic acid [21]. The only precedent of a glycoprotein expressed in plants for vaccine development is the glycoprotein $\mathrm{G}$ of rabies virus [22]. This protein expressed in tomato plants showed a molecular mass about four and six $\mathrm{kDa}$ less than that obtained from virus-infected cells but still larger than the unglycosylated polypeptide chain [22]. The molecular mass of glycoprotein S expressed in Arabidopsis thaliana could not be determined because we were not able to detect the recombinant protein in Western blotting. However, antigenic determinants with strong dependence of glycosylation seem to be preserved since the plant-derived antigens induced neutralizing antibodies in immunized animals, indicating that critical antigenic sites are at least in part correctly glycosylated in plants.

\section{Die beschriebenen Versuchsergebnis- se belegen die prinzipielle Machbar- keit einer Expression viraler Glyko- protein-Polypeptide in Pflanzen und deren Verwendung zur Immuni- sierung.}

The above described work demonstrates the feasibility of expressing glycoprotein $S$ polypeptides in plants. Because the site of insertion of the transferred DNA into the cellular chromosomal DNA is random, different levels of protein expression in independent transformants are expected. We obtained expression levels similar to that described with equivalent constructs expressing hepatitis B surface antigen or rabies virus glycoprotein $[8$, 22]. More recently, expression levels of Norwalk virus capsid protein in tobacco have been shown to be higher than the above mentioned antigens (up to $0.23 \%$ of total soluble protein) [10]. We have not found significant differences in foreign antigen plant expression between the two forms of glycoprotein $S$ studied or among the different plants transformed. The use of different promoters, the use of plant-derived leader sequences and signal peptides, and mainly the modification of the codon usage of this protein could improve expression levels in plants.

\section{Outlook}

The demonstration that many proteins from pathogens, including some expressed in transgenic plants $[9,10,11]$, are immunogenic when administered orally, encourage the study of other antigens expressed in plants to develop edible vaccines. Glycoprotein S from TGEV is an interesting model since this protein is resistant, at least when incorporated into the viral particle, to the gut degradation. In addition, the protective immune responses against TGEV have to be stimulated at the mucosal surfaces in order to induce secretory and lactogenic immunity $[4,23,24,25]$. In the above described work, we have demonstrated that the N-terminal domain of glycoprotein $S$ expressed in potato tubers is immunogenic when mice were fed with the transgenic potatoes [26]. In conclusion, these results make reasonable to extend similar immunological studies in pregnant sows, in order to test the lactogenic immunity conferred to suckling piglets by the plant-derived glycoprotein S.

\section{References}

1. Garwes DJ, Lucas MH, Higgins DA, Pike BV, Cartwright SF (1978) Antigenicity of structural components from porcine transmissible gastroenteritis virus. Vet Microbiol 3 : 179-190

2. Jiménez G, Correa I, Melgosa MP, Bullido MJ, Enjuanes L (1986) Critical epitopes in transmissible gastroenteritis virus neutralization. J Virol 60: 131-139

3. Correa I, Jiménez G, Suñé C, Bullido MJ, Enjuanes $L$ (1988) Antigenic structure of E2glycoprotein of transmissible gastroenteritis coronavirus. Virus Res 10:77-94

4. De Diego M, Laviada MD, Enjuanes L, Escribano JM (1992) Epitope specificity of protective lactogenic immunity against swine transmissible gastroenteritis virus. J Virol 66: 6502-6508

5. Delmas B, Rasschaert D, Godet M, Gelfi J, Laude $H$ (1990) Four major antigenic sites of the coronavirus transmissible gastroenteritis virus are located on the amino-terminal half of spike glycoprotein S.J Gen Virol 71: 1313-1323

6. Sánchez CM, Jiménez G, Laviada MD, Correa I, Suñé C, Bullido MJ, Gebauer F, Smerdou C, Callebaut P, Escribano JM, Enjuanes L (1990) Antigenic homology among coronaviruses related to transmissible gastroenteritis virus. Virology 174:410-417 
7. Torres JM, Alonso C, Ortega A, Mittal S, Graham F, Enjuanes L (1996) Tropism of human adenovirus type 5-based vectors in swine and their ability to protect against transmissible gastroenteritis coronavirus. J Virol 70: 3770-3780

8. Mason HS, Lam DM-K, Arntzen CJ (1992) Expression of hepatitis $B$ surface antigen in transgenic plants. Proc Natl Acad Sci USA 89:11745-11749

9. Haq TA, Mason HS, Clements JD, Arntzen CJ (1995) Oral immunization with a recombinant bactíerial antigen produced in transgenic plants. Science 268:714-716

10. Mason HS, Bali JM, Shi JJ, Jiang X, Estes MK, Arntzen CJ (1996) Expression of Norwalk virus capsid protein in transgenic tobacco and potato and its oral immunogenicity in mice. Proc Natl Acad Sci USA 93:5335-5340

11. Wigdorovitz A, Carrillo C, Dus Santos MJ, Trono K, Peralta A, Gómez MC, Ríos RD, Franzone PM, Sadir AM, Escribano JM, Borca MV (1999) Induction of a protective antibody response to foot and mouth disease virus in mice following oral or parental immunization with alfalfa transgenic plants expressing the viral structural protein VP1. Virology 255:347-353

12. Thanavala $Y$, Yang YF, Lyons $P$, Mason HS, Arntzen C (1995) Immunogenicity of transgenic plant-derived hepatitis B surface antigen. Proc Natl Acad Sci USA 92: 3358-3361
13. Carrillo C, Wigdorovitz A, Oliveros JC, Zamorano PI, Sadir AM, Gómez N, Salinas J, Escribano JM, Borca MV (1998) Protective immune response to foot-and-mouth disease virus with VP1 expressed in transgenic plants. JVirol 72: 1688-1690

14. Arakawa I, Chong DKX, Langridge WHR (1998) Efficacy of a food plant-based oral cholera toxin B subunit vaccine. Nat Biotech 16: 292-297

15. Gómez N, Carrillo C, Salinas J, Parra F, Borca MV Escribano JM (1998) Expression of immunogenic glycoprotein $S$ polypeptides from Transmissible gastroenteritis coronavirus in transgenic plants. Virology 249:352-358

16. Castañón S, Marín MS, Martín-Alonso JM, Boga JA, Casals R, Humara JM, Ordás RJ, Parra F (1999) Immunization with potato plants expressing VP60 protein protects against Rabbit hemorrhagic disease virus. J Virol 73:4452-4455

17. Baulcombe DC, Saunders GR, Bevan MW, Mayo MA, Harrison BD (1986) Expression of biologically active viral satelite RNA from nuclear genome of transformed plants. Nature 321:446-449

18. Bechtold N, Ellis J, Pelletier G (1993) Agrobacterium mediated gene transfer by infiltration of adult Arabidopsis thaliana plants. C R Acadl Sci Paris Sciences de la vie 316:1194-1199

19. Gebauer F, Posthumus WPA, Correa I, Suñé C, Smerdou C, Sánchez CM, Lenstra JA, Leloen RH, Enjuanes $L$ (1991) Residues involved in the antigenic sites of transmissible gastroenteritis coronavirus $\mathrm{S}$ glycoprotein. Virology 183:225-238

20. Hu 5, Bruszewski J, Smallig R, Browne JK (1987) Studies of TGEV spike protein GP195 expressed in E. coli and by a TGEV-vaccinia virus recombinant. In:Zouhair Attasi $M$, Bachrach HL (eds) Immunobiology of Proteins and Peptides. II.Viral and Bacterial antigens. Plenurn Press, New York, p 63
21. Faye L, Fitchette-Laine AC, Gomord V, Chekkati A, Delaunay AM, Driouich A (1993) Detection, biosynthesis and some functions of glycans $\mathrm{N}$-linked to plant secreted proteins. Society for Experimental Biology Seminar Series 53:213-242

22. McGarvey PB, Hammond J, Dienelt MM, Hooper DC, Fu ZF, Dietzschold B, Koprowski H, Michaels $\mathrm{FH}$ (1995) Expression of the rabies virus glycoprotein in transgenic tomatoes. Biotechnology 13: 1484-1487

23. De Diego M, Rodríguez F, Alcaraz C, Gómez N, Alonso C, Escribano JM (1994) Characterization of the $\lg A$ and subclass $\lg G$ responses to neutralizing epitopes after infection of pregnant sows with the transmissible gastroenteritis virus or the antigenically related porcine respiratory coronavirus. J Gen Virol 75:2585-2593

24. Saif $L J$, Bohl EH (1979) Passive immunity in transmissible gastroenteritis of swine: immunoglobulin classes of milk antibodies after oral-intranasal inoculation of sows with a live low cell culture-passaged virus. Am J Vet Res 40:115-117

25. Wesley RD, Woods RD, Correa I, Enjuanes L (1988) Lack of protection in vivo with neutralizing monoclonal antibodies to transmissible gastroenteritis virus. Vet Microbiol 18:197-203

26. Gómez N, Wigdorovitz A, Castañón S, Gil F, Ordás R, Borca MV, Escribano JM (1999) Oral immunogenicity of glycoprotein $\mathrm{S}$ from Transmissible gastroenteritis coronavirus expressed in transgenic plants. Submitted to publication 